\title{
Population Ageing and the Ecology in China: Towards a Balanced Developmental Strategy Model
}

\author{
$\underline{\text { Xiumei Guo }}{ }^{1}$, Dora Marinova ${ }^{1}$ and Ruiyue $\mathrm{Jia}^{2}$ \\ ${ }^{I}$ Curtin University Sustainability Policy (CUSP) Institute, Curtin University \\ ${ }^{2}$ School of Management, University of Science and Technology of China \\ Email: x.guo@curtin.edu.au
}

\begin{abstract}
As the most populous country in the world, China is enjoying unprecedented economic growth, but this development has caused serious degradation of the country's physical environment. The issues are particularly aggravated with China's quickly expanding urbanisation and ageing population. Based on recent data, this paper analyses China's demographic profile and explores the country's ecological deterioration issues in order to seek a balanced economic developmental strategy model. Through cluster analysis, the paper explores the influences of population change and economic growth on the environment with the purpose of providing some valuable knowledge and lessons for achieving a quality economic growth for China. It argues that changes have to be made to ease the double burden of restoring the deteriorating ecosystems and dealing with the ageing crisis in the country.
\end{abstract}

Keywords: Population Census, environment, cluster analysis, province 
Guo et al., Population ageing and the econology in China: Towards a balanced development...

\section{INTRODUCTION}

As the world's fastest growing developing country, China has attracted a lot of global attention for the extensive pressure from its fast growing ageing population, use of limited resources as well as the deteriorating ecological environment. China's resources, energy and environmental issues have become a serious constraint for its economic development, social advancement and ecological balance. Urban air pollution has been attracting both domestic and international attention (UNEP, 2010) and the country's ageing crisis is creating more pressure for the government to deal with the quickly expanding ecological challenges. This paper explores China's demographic trends and environmental issues. This study explores the relationship between population ageing and the ecology, using an integrated environmental index model (Table 1 and equation 1). We use cluster analysis based on the results from China's integrated environmental index and 2009 statistical population data to shed light on ageing trends and environmental characteristics at the provincial level. The conclusions provide a summary of the issues with policy implications.

\section{FAST POPULATON AGEING IN CHINA}

According to the latest $6^{\text {th }}$ Population Census, China's population has reached 1.34 billion in 2010. As the most populous country in the world, the country's population is still growing (Table 1) because of its relatively young composition (Figure 2). China's population growth has significant impacts on the country's natural resources. On the other hand, ecological deterioration and growing pressure on the environment increasingly influence the quality of people's life, and particularly the old people. At the moment the Chinese government has to handle the nation's ageing crisis triggered mainly by its one-child family planning policy. Its implementation since 1979 has significantly reduced the share of young and working age people (Figure 2). It was one of the important factors that helped China reduce its total fertility rate from almost 4 children per woman in 1970s to 1.8 in 2010 with this rate projected to remain stable for the next 4 decades (UN, 2010; Jackson, 2011). The one-child policy was critical to slow down the nation's population growth rate, but it has also brought about a lot of challenges to China. This is mostly reflected in the fact that population ageing in China has been growing fast with the rapid decline of the country's fertility and mortality.

China, as a large developing country, has to face the ageing crisis in its severely deteriorating environment. China's large ageing population is an unfavourable factor for achieving the country's social and economic prosperity and its current development is causing a negative impact on its natural environment. The reductions in fertility and mortality rates are producing a fundamental change in the age structure of the population clearly seen in its population pyramids (Figure 2) and increasing life expectancy (Figure 3). In 2050, China will have over 100 million people aged 80 or over and the share of the labour force covered by pension systems will remain low at just 20\%, which is less than half of the averaging $44 \%$ in East Asia (UN, 2010). As developing country, it can be imagined what this situation will bring in the future as China's elderly share will increases from $5 \%$ in 1980 to $24 \%$ in 2050 (Jackson, 2011) and the share of its working age population dramatically decreases (Figure 4).

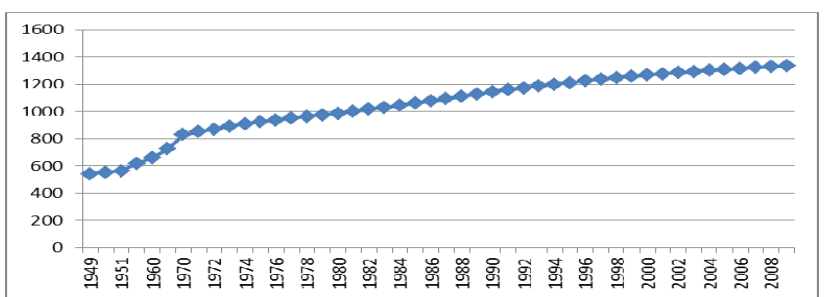

Figure 1 Population growth in China, 1949-2009

Source: Compiled from National Bureau of Statistics (2010)

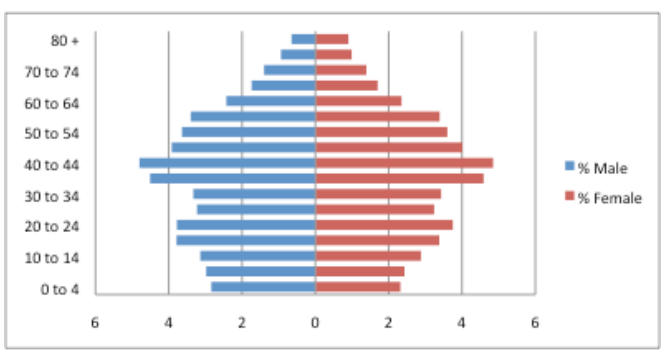

Figure 2 Population pyramid of China, 2010

\section{Provincial ageing levels in China}

The $6^{\text {th }}$ Population Census shows that China's population of 65 year and over is almost 12 million or $8.9 \%$ of total population, a significant increase from the $1.9 \%$ in the previous 2000 census. Using provincial statistical data on ageing, we present the results from a cluster analysis which divided China's 30 provinces into 5 categories (Figure 5 and Table 2). The imbalance in the socioeconomic development of the regions is reflected in the imbalance in China's ageing and population structure trends. For example, Shanghai's ageing population share at $14.1 \%$ is much higher than that for other provinces and is in the "highest" category. However, the average share of ageing people in Ningxia, Xinjiang, Qinghai and Guangdong provinces is $6.98 \%$, which is only half of the Shanghai's level. Therefore, there is a serious regional imbalance in the ageing trends in China. On the other hand, the average per capita total GDP is 35591 yuan in the provinces in the "lowest" category, which is in average higher than the provinces with ageing trends at the "higher", 
Guo et al., Population ageing and the econology in China: Towards a balanced development...

"medium" and "lower" categories. Therefore, China is phenomenally getting old before it gets rich with a structural imbalance (Yang and Wang, 2011; Wee, 2011). It is obvious that China's regional imbalance in ageing and structure will make the country face significant challenges for providing social security to its fast growing ageing population, which would create serious social and economic issues without proper governance and measures (Zhao, 2011).

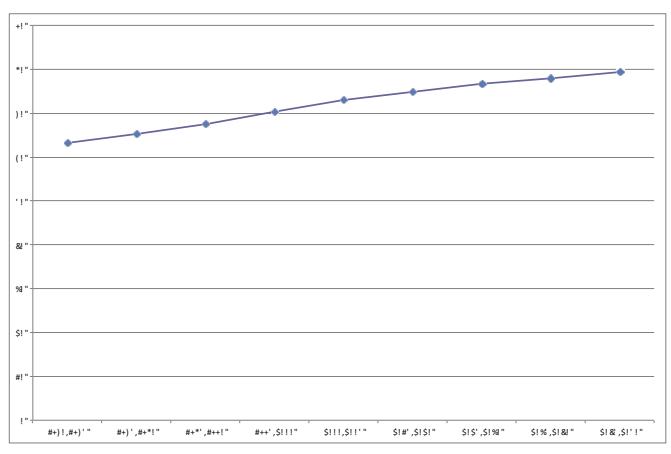

Figure 3 Life expectancy in China 1970-2050 Source: Jackson (2011)

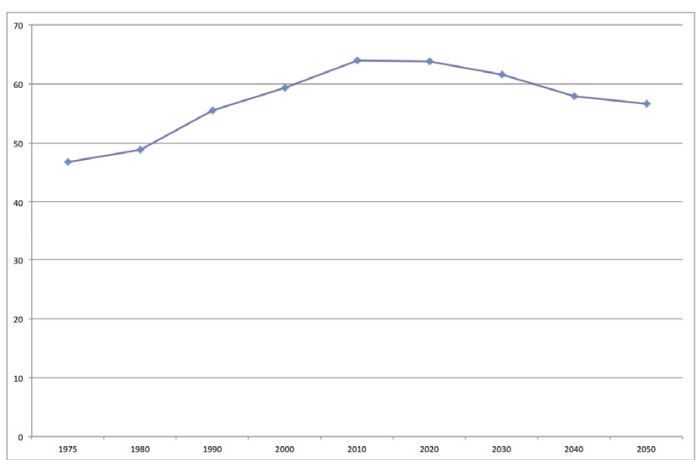

Figure 4 Working-age share in China, 1975-2050 Source: Jackson (2011)

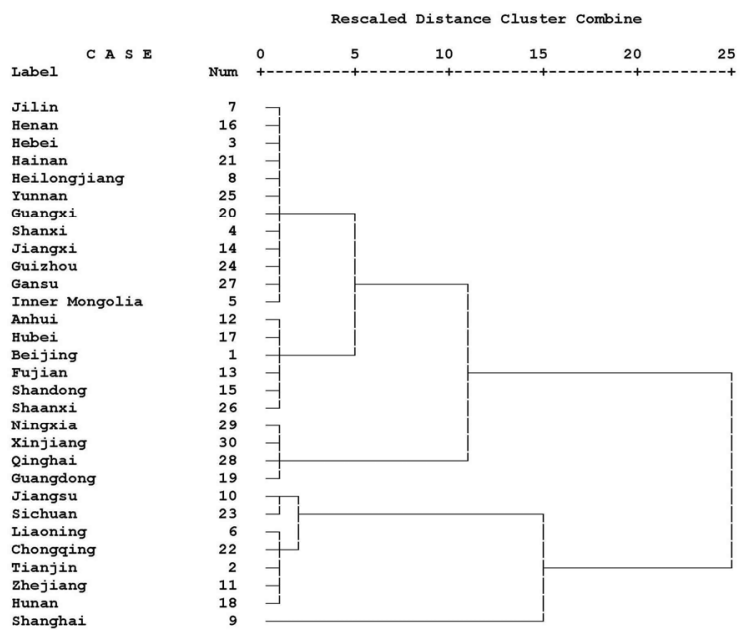

Figure 5 Results from cluster analysis of China's ageing population

Table 1 Provincial categories of China's ageing levels

\begin{tabular}{|c|c|c|c|c|c|}
\hline Categories & Highest & Higher & Medium & Lower & Lowest \\
\hline Provinces & Shanghai & \begin{tabular}{|l|} 
Jiangsu, \\
Sichuan, \\
Liaoning, \\
Chongqing, \\
Tianjin, \\
Zhejiang, \\
Hunan \\
\end{tabular} & \begin{tabular}{|l|} 
Anhui, \\
Hubei, Beijing, \\
Fujian, \\
Shandong, \\
Shaanxi
\end{tabular} & $\begin{array}{l}\text { Jilin, Henan, Hebei, } \\
\text { Hainan, Heilongjiang, } \\
\text { Yunnan, Guangxi, } \\
\text { Shanxi, Jiangxi, } \\
\text { Guizhou, Gansu, Inner } \\
\text { Mongolia }\end{array}$ & $\begin{array}{l}\text { Ningxia, } \\
\text { Xinjiang, } \\
\text { Qinghai, } \\
\text { Guangdong }\end{array}$ \\
\hline $\begin{array}{l}\text { Proportion of } \\
\text { Ageing Population } \\
(\%)\end{array}$ & 14.08 & 11.51 & 10.01 & 8.60 & 6.98 \\
\hline $\begin{array}{l}\text { Per Capita GRP } \\
\text { (yuan) }\end{array}$ & 78326 & 31732 & 29361 & 20007 & 35591 \\
\hline
\end{tabular}

Source: Authors calculation from China Statistical Bureau (2010) 
Guo et al., Population ageing and the econology in China: Towards a balanced development...

In addition, according to the forecasts of the National Bureau of Statistics (2010), China's supply of labour force resources will be gradually decreasing after 2013. It has been proven in Japan and other ageing countries that the decreasing labour force supply delays economic growth.

\section{ECOLOGICAL DETERIORATION}

With the miraculous economic expansion for the last 3 decades, China is suffering from degradation of its natural resources (e.g. serious water, land and air pollution) due to the country's increasing industrialization and urbanization. Uncontrolled deforestation and improper land use practices cause soil erosion (UNEP, 2002). Green algae pollution in China's major rivers and beaches is a frequent phenomenon due to mismanagement of water (Xinhuanet 2011). The ageing population needs sound environment for their health and wellbeing, such as sufficient land use for beautiful parks, clean air and fresh water. However there is evidence that arable land in China is shrinking due to industrialization and urbanization (China Daily, 2010). The number of cars is growing quickly; for example, according to car sales in 2009 China has already overtaken USA and by 2010 it was almost double the number of cars sold in USA (China Daily, 2011). Air and water pollution have resulted in problems affecting the whole country. Water shortage is already a big problem in China. For example, the country's per capita water resources availability will drop significantly in 2030 when China's population is expected to reach 1.6 billion with a water-scarcity limit at $1,700 \mathrm{~m}^{3}$ (Wan and Zhou, 2009).

\section{Provincial environmental performance in China}

Using the established evaluation model of regional environmental comprehensive index shown in Table 2 (and explained in Appendix 1), this paper evaluated the provincial comprehensive environmental indexes for 2009 and conducted a cluster analysis for environmental indexes. The results of the cluster analysis are shown in Figure 6 and the resulting categories of the provincial analysis are presented in Table 3. It can be seen that China's provincial comprehensive environmental performance gap is large. Beijing's comprehensive environmental index at 3.69 is in the "excellent" category, and is nearly 4 times of Ningxia's comprehensive environmental index which is in the "poor" category. Economic development in Beijing is relatively high and provides a stronger ability to solve environmental problems. Due to the strict environmental regulations undertaken before and during the 2008 Beijing Olympic Games, the city's comprehensive environmental performance is relatively good. The comprehensive environmental performance in Ningxia is the lowest due to its delayed economic development, which does not allow it to solve relatively quickly its environmental problems.

Table 2 Integrated environmental index

\begin{tabular}{|c|c|c|c|}
\hline & Indicator & Status & Weight \\
\hline \multirow{10}{*}{$\begin{array}{l}\text { Integrated } \\
\text { Environmental } \\
\text { Index }\end{array}$} & $\begin{array}{l}\text { Industrial waste water discharged per unit of GDP (ton/ten } \\
\text { thousand Yuan) }\end{array}$ & negative & 0.1 \\
\hline & $\begin{array}{l}\text { Industrial waste gas discharged per unit of GDP }\left(\mathrm{m}^{3} / \mathrm{ten}\right. \\
\text { thousand Yuan) }\end{array}$ & negative & 0.1 \\
\hline & Cultivated land per capita (hectare ) & positive & 0.1 \\
\hline & Water resource per capita $\left(\mathrm{m}^{3}\right)$ & positive & 0.1 \\
\hline & Accumulation of live timber per capita $\left(\mathrm{m}^{3}\right)$ & positive & 0.1 \\
\hline & Forest coverage rate $(\%)$ & positive & 0.1 \\
\hline & $\begin{array}{l}\text { Rate of industrial waste water meeting discharge standards } \\
(\%)\end{array}$ & positive & 0.1 \\
\hline & Rate of industry sulphur dioxide removed (\%) & positive & 0.1 \\
\hline & Rate of industrial solid wastes treated (\%) & positive & 0.1 \\
\hline & $\begin{array}{l}\text { Ratio of investment in the treatment of industrial pollution } \\
\text { to GDP }(\%)\end{array}$ & positive & 0.1 \\
\hline
\end{tabular}


Guo et al., Population ageing and the econology in China: Towards a balanced development...

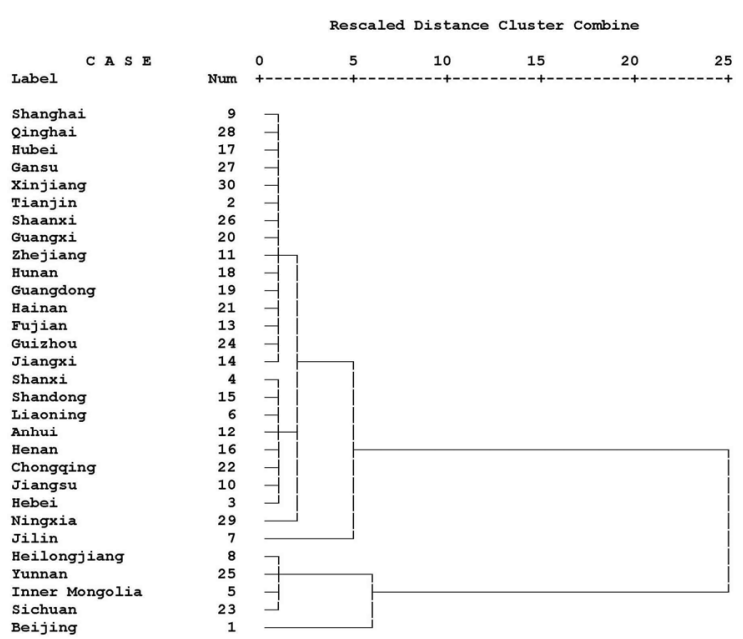

Figure 6 Results from cluster analysis of China's comprehensive environmental indexes

Table 3 Categories of China's provincial comprehensive environmental indexes

\begin{tabular}{|l|c|c|c|l|l|l|}
\hline Categories & Excellent & Very & Good & \multicolumn{1}{|c|}{ Fair } & Poor & Poorer \\
\hline Provinces & Beijing & $\begin{array}{l}\text { Heilongjiang, } \\
\text { Yunnan, Inner } \\
\text { Mongolia, } \\
\text { Sichuan }\end{array}$ & Jilin & $\begin{array}{l}\text { Shanghai, Qinghai, Hubei, } \\
\text { Gansu, Xinjiang, Tianjin, } \\
\text { Shaanxi, Guangxi, } \\
\text { Zhejiang, Hunan, } \\
\text { Guangdong, Hainan, } \\
\text { Fujian, Guizhou, Jiangxi }\end{array}$ & $\begin{array}{l}\text { Shandong, } \\
\text { Shandiang, } \\
\text { Liaoning, } \\
\text { Anhui, Henan, } \\
\text { Chongqing, } \\
\text { Jiangsu, Hebei }\end{array}$ & Ningxia \\
\hline $\begin{array}{l}\text { Comprehensive } \\
\text { Environmental } \\
\text { Indexes }\end{array}$ & 3.69 & 2.93 & 2.15 & 1.66 & 1.29 & 0.98 \\
\hline $\begin{array}{l}\text { Per Capita GRP } \\
\text { (Yuan) }\end{array}$ & 69248 & 20337 & 26569 & 28383 & 28588 & 21646 \\
\hline
\end{tabular}

Source: Authors calculation from China Statistical Bureau (2010)

The higher environmental index indicates better environmental condition and performance, such as lower level of carbon emissions, better ecological environment and more environmentally friendly society. The comparison between the comprehensive environmental indexes and the per capita regional total GDP of provinces demonstrates the "N" distribution in the relationship between the provincial comprehensive environmental indexes and the level of economic development. Therefore, according to the results of the cluster analysis, it is not always correct to conclude that economic development can cause environmental deterioration. What China has to solve for the future development is to assist Ningxia and other backward regions to reduce their environmental pollution in order to improve environmental quality and promote their environmental performances through investing in environmental management, restructuring the economy and making the shift to green technologies.

\section{CONCLUSION}

China's population is ageing faster due to the lower fertility, mortality and longer life expectancy. The country also has severe environmental problems. The Chinese government has concentrated on economic growth without paying enough attention to environmental deterioration. The issues are particularly aggravated with China's quickly expanding ageing population and urbanization. With China's ageing crisis, it is vital to start resolving ecological problems soon. However, there is concern about whether China can maintain a quality economic growth and preserve its water and other limited natural resources while providing a sufficient service to the country's growing number of older people. In the future, China will have to face not only the increasing pressure on the limited natural resources due to the large and growing population, but also ecological burden due to continuing industrialization and urbanization. Solving China's environmental problems, such as carbon emissions, land erosion and degradation, air and water pollution will add more pressure on the population in the country. In order to be able to successfully sustain its growth, 
Guo et al., Population ageing and the econology in China: Towards a balanced development...

China should establish a more effective system and strategy of resources development and the government should strengthen the supervision of resources management and protection.

The socioeconomic impact of an ageing population is significant in China. In areas with a high concentration of elderly people there may be pressure on local government planning processes to provide sufficient land, general transport and infrastructure for aged care. Education, aged care, disability support and pension costs will affect resources conservation investments. The ecological issues created by the country's pursuing GDP growth are getting more serious and China needs to be prepared simultaneously to challenge all of these difficulties. In fact, there is need for the governments to seek a balanced developmental strategy model to achieve this.

China will have to cope with the additional challenge to face the country's massive size of elderly population and the gigantic impact that it can potentially bring. The ageing population will cause an increased demand for the aged service, social security, pension and more health care expenditures. The labour force participation rate will fall with ageing and the decrease of working age population in China will have negative impacts on China's economic expansion.

Furthermore, health care will be more challenging under the current complicated situation of China's imbalanced regional levels in ageing, economic development and environmental performance. Therefore China has to invest more resource capital and human capital to ensure the country's growing economy.

In response to the serious environmental issues and ageing crisis, the Chinese government has recently set a lower annual growth target of 7\% for the country's $12^{\text {th }}$ Five-Year Plan period (2011-2015). It is hoped that this will ensure a better balance among economic prosperity, environmental protection and quality of life. Making steady progress towards quality health care and old age pension becomes a major component of the current Five-Year Plan which reevaluates the current concept of GDP quality, social advancement and natural resource conservation. A more balanced strategy will help service providers and policy makers to address the challenges triggered by the fast growing population ageing and ecological deterioration.

\section{ACKNOWLEDGEMENT}

The first two authors want to acknowledge the financial support of the Australian Research Council.

\section{REFERENCES}

China Daily (2010). Shrinking arable land threatens grain security, http://www.chinadaily.com.cn/china/2010-10/18/content_11423618.htm. Accessed July 22, 2010

China Daily (2011). 2010 auto sales driven to a record,

http://www.chinadaily.com.cn/business/2011-01/11/content 11823998.htm. Accessed July 12, 2011

China Statistical Bureau (2010), China Statistical Year Book, China Statistical Press, Beijing

Jackson, R. (2011), Special Report: China's Economy Can an Aging China Be a Rising China? https://www.chinabusinessreview.com/public/1104/jackson.html (22.07.2011)

National Bureau of Statistics (NBS) (2010) Statistical Yearbook of China 2010, Statistical Publishing Press, Beijing

United Nations (UN) (2010). World Population Ageing 2009, Economic and Social Affairs Population Division ST/ESA/SER.A/295, New York

United Nations Environment Programme (UNEP) (2002). State of the environment and policy retrospective, 1972-2002, UNEP, www.unep.org/GEO/geo3/english/pdfs/chapter2-2_land.pdf (22.08.2011)

United Nations Environment Programme (UNEP) (2009). Expo 2010: Shanghai, China. http://www.unep.org/publications/contents/pub_details_search.asp?ID=4040 (accessed May 25, 2011)

Wan, Y. X. and C. Y. Zhou (2009) The goals, challenges and countermeasures for the harmonious development between human beings and water. Yellow River, 31(6): 18-19, 118

Wee, S. (2011). China risks getting old before it gets rich,

http://www.reuters.com/article/2011/04/27/us-china-demography-idUSTRE73Q1SC20110427 accessed July 2, 2011

Xinhuanet (2011). Green Algae invading China's tourist destination Qingdao, http://news.xinhuanet.com/english2010/china/2011-07/08/c_13973813_2.htm. accessed July 20, 2011

Yang, D. and M. Wang (2011). Population ageing, domestic consumption and future economic growth in China, in Rising China: Global Challenges and Opportunities by Golley, J. and L. Song (eds). ANU E Press, Canberra and Social Sciences Academic Press 
Guo et al., Population ageing and the econology in China: Towards a balanced development...

Zhao, Z. (2011). China's demographic challenges from a global perspective in Rising China: Global Challenges and Opportunities by Golley, J. and L. Song (eds). ANU E Press, Canberra and Social Sciences Academic Press

\section{APPENDIX 1}

\section{Evaluation method}

Due to measurement and dimension differences, all indicators require to be standardised before calculating the three indices. To ensure comparability of the aggregate indices across regions, we use the 2003 average value for each indicator as a benchmark as shown in equation (1).

$$
C_{i j}=\left\{\begin{array}{l}
c_{i j} / c_{i}^{2003}, \text { when the } i \text { th indicator is positive } \\
c_{i}^{2003} / c_{i j}, \text { when the } i \text { th indicator is negative }
\end{array}\right.
$$

where $C_{i j}$ indicates the $i^{\text {th }}$ standardised indicator for region $j, c_{i j}$ is the original value of the $i^{\text {th }}$ indicator for region $\mathrm{j}$, and $\mathrm{c}_{\mathrm{i}}{ }^{2003}$ is the $\mathrm{i}^{\text {th }} 2003$ national average value. The environmental index represents the weighted sums of the contributing indicators as shown in equation (2)

$\mathrm{E}_{j}=\sum \mathrm{C}_{i j} \times \mathrm{W}_{i}$

where $\mathrm{E}_{j}$ indicate environmental index for region $j, 0<\mathrm{W}_{\mathrm{i}}<1$ is the weight of the $i^{\text {th }}$ indicator. Despite its subjective and arguable nature, we have opted for the widely used expert scoring for determining the indicators' weight in the aggregate index as objective weighting is impossible to achieve. 